$\begin{array}{llllllll}\mathbf{A} & \mathbf{R} & \mathbf{T} & \mathbf{Y} & \mathbf{K} & \mathbf{U} & \mathbf{L} & \mathbf{Y}\end{array}$

Collectanea Theologica

$85(2015) \mathrm{nr} 4$

WALDEMAR CHROSTOWSKI, WARSZAWA

\title{
TŁO HISTORYCZNE I SPOŁECZNE NAUCZANIA PROROKA AMOSA
}

Księga Amosa jest trzecią w zbiorze Dwunastu w Biblii Masoreckiej oraz drugą w zbiorze Proroków mniejszych w Septuagincie. Usytuowanie między Księgą Joela a Księgą Abdiasza można uzasadnić tym, że w tych trzech księgach wyraźnie przewija się temat Dnia Pańskiego (Jl 1,15; Am 5,18-20; Abd 15). ${ }^{1}$ Z kolei usytuowanie Księgi Amosa po Księdze Ozeasza a przed Księgą Micheasza, przyjęte w Biblii Greckiej, respektuje wspólny czas życia i działalności tych proroków, który przypadł na VIII w. przed Chr. To sprawia, że odzwierciedlają one uwarunkowania historyczne, kulturowe, społeczne, ekonomiczne i religijne charakterystyczne dla schyłkowego okresu istnienia królestwa Izraela, które w 722 r. przed Chr. padło pod ciosami Asyryjczyków i przestało istnieć.

\section{Datowanie dzialalności i nauczania Amosa}

Informacje zawarte w Księdze Amosa pozwalają precyzyjnie ustalić czas życia i działalności głównego bohatera, często określanego mianem ,„proroka sprawiedliwości społecznej”. ${ }^{2}$ Bardzo ważna informacja, która dostarcza wiedzy na temat Amosa, pojawia się w nagłówku, który jest dziełem redaktora księgi: ${ }^{3}$ „Słowa Amosa,

M. A. S w e e n e y, Amos, w: t e n ż e, The Twelve Prophets, t. 1, Berit Olam. Studies in Hebrew Narrative and Poetry, Collegeville, MI 2000, s. 191.

2 Zob. A. B o n or a, Amos. Il Profeta della giustizia, Brescia 1979; G. W i t a s z e k, Amos - prorok sprawiedliwości społecznej, Lublin 1996.

3 G. M. Tu cke r, Prophetic Superscriptions and the Growth of a Canon, w: B. O. L ong, G. W. C o at s (red.), Canon and Authority, Philadelphia 1977, s. 56-70; zob. M. S z m a j d z i ń s k i, Amos - pasterz i prorok (Am 1,1; 7,14. n.), w: W. Ch ro st o w s k i (red.), ,,Stworzył Bóg człowieka na swój obraz”. Księga 
który był jednym spośród pasterzy z Tekoa; co widział w sprawie Izraela, za dni Ozjasza, króla Judy, i za Jeroboama, syna Joasza, króla Izraela, na dwa lata przed trzęsieniem ziemi" $(1,1)$. Mamy tu po dwa konkretne odniesienia geograficzne (Tekoa, Izrael) ${ }^{4}$ i historyczno-polityczne (Ozjasz, Jeroboam) oraz wzmiankę o profilu historyczno-psychologicznym (,dwa lata przed trzęsieniem ziemi”).

Nazwa „Tekoa” może oznaczać miasto, położone na południowy-wschód od Betlejem, ${ }^{5}$ jak i sąsiadujący z nim fragment pustyni (2Krn 20,20). ${ }^{6}$ Według Drugiej Księgi Kronik $(11,6)$, umocnił je i otoczył murem król Roboam, syn i następca Salomona na tronie królestwa Judy. Wzmianka o Tekoa w Księdze Jeremiasza $(6,1)$ świadczy, że osada stanowiła bardzo dobry punkt obserwacyjny, skąd można było uprzedzić mieszkańców Jerozolimy o zbliżającym się niebezpieczeństwie. Ponieważ w starożytności w tej okolicy brakowało odpowiednich warunków do uprawy roli i rozwoju rolnictwa, mieszkańcy, wśród nich Amos, trudnili się głównie pasterstwem. Wzmianka o nacinaniu sykomor (Am 7,14) sugeruje, że Amos był właścicielem pola, na którym uprawiał drzewa owocowe, jednak nie w Tekoa, gdzie wilgotność gleby nie wystarczała na uprawy, lecz dalej, zapewne w pobliżu Betlejem. Tekoa, położone na terytorium królestwa Judy z stolicą w Jerozolimie, istniało w okresie Pierwszej Świątyni, czyli między X a VI w. przed Chr. Wzmianka o Izraelu, czyli państwie północnym ze stolicą w Samarii, które istniało od ok.

pamiątkowa dla Biskupa Profesora Mariana Gotębiewskiego w 65. rocznicę urodzin, Warszawa 2002, s. 405-417; P. W a s z a k, Od pracy sezonowej do Bożej stużby. Głos $w$ dyskusji na temat osoby i powolania ,pasterza z Tekoa” oraz ,nacinacza sykomor - Widzacego" (Am 1,1n.; 7.12.14b-15), Collectanea Theologica 81(2011) nr 2, s. 39-48.

4 Zob. M. E. A nd rew, Places, Times and Identities in the Book of Amos, Asia Journal of Theology 14/2000, s. 328-344.

5 Domysły, że Amos pochodził z innej miejscowości o tej samej nazwie, usytuowanej w Galilei, o tyle nie mają racji bytu, że jest to miejscowość znana dopiero z czasów pobiblijnych.

6 Tekoa, w: P. J. A c h t e m e i e r (red. nauk.), W. C h r o s t o w s k i (red. nauk. wyd. pol.), Encyklopedia biblijna, Prymasowska Seria Biblijna 9, Warszawa 2004², s. 1239. 
930 do 722 r. przed Chr., pozwala uściślić ów przedział czasowy, sytuując życie i działalność Amosa przed zagładą Samarii i asyryjskimi deportacjami Izraelitów.

W ogólniejsze ramy wyznaczone uwarunkowaniami geograficznymi i topograficznymi wpisują się informacje historyczne. Są to szczegółowe nawiązania do Ozjasza, króla Judy, i Jeroboama, syna Joasza, króla Izraela. Aczkolwiek bardzo dokładna chronologia panowania władców królestwa Judy i królestwa Izraela nadal pozostaje przedmiotem dyskusji, różnice w szacunkach nie są duże i wynoszą najwyżej kilka lat. Ponieważ chodzi o sytuację sprzed ponad dwóch i pół tysiąclecia, możemy być zadowoleni, że nasze rozeznanie jest tak dokładne. Panowanie Ozjasza, zwanego Azariaszem (2Krl 14,21; 15,1-8; 17,27; 1Krn 3,12), syna Amazjasza i ojca Jotama, jest datowane na lata ok. 783-742. ${ }^{7}$ Tak samo długie, bo trwające 41 lat (ok. 787-748), ${ }^{8}$ było panowanie Jeroboama II, syna Joasza, w królestwie Izraela. Okres długich rządów obu władców zbratanych, lecz i silnie zantagonizowanych, państw pokrywał się więc ze sobą.

Duże znaczenie ma również informacja „na dwa lata przed trzęsieniem ziemi”. Trzęsienia ziemi w tej części Bliskiego Wschodu były zjawiskiem częstym i mocno naznaczały pamięć mieszkańców. Tak charakterystyczna wzmianka świadczy, że adresaci Księgi Amosa dobrze wiedzieli o co chodzi, bo wciąż trwała wśród nich pamięć o kataklizmie. O jego rozmiarach może świadczyć aluzja w Księdze Zachariasza 14,4-5: wzmianka o rozstąpieniu się Góry Oliwnej bywa interpretowana jako nawiązanie do szczeliny między górą Skopus a Górą Oliwną, powstałej w wyniku silnego trzęsienia ziemi. Taka sugestia opiera się na relacji Józefa Flawiusza na temat okoliczności, w jakich Azariasz, król Judy, został dotknięty trądem. ${ }^{9}$ Rozstrzy-

7 S. H. Hor n, P. Ky le M c C a r te r jr, Podzielona monarchia. Królestwa Judy i Izraela, w: H. S h a n k s (red.), Starożytny Izrael. Od Abrahama do zburzenia światyni jerozolimskiej przez Rzymian, W. C h r o s t o w s k i (tłum.), Podręczniki Biblijne 1, Warszawa 20133, s. 201.

8 Tamże.

9 Opisując kultowe nadużycia Azariasza względem świątyni jerozolimskiej, F law i u s z podaje: „Nie domówił jednak jeszcze tych słów, gdy nagle ziemia 
gającego argumentu dostarcza archeologia: prace wykopaliskowe w Lakisz odsłoniły liczne ślady trzęsienia ziemi datowanego na ok. 760 r. przed Chr. ${ }^{10}$ Spowodowana nim trauma była tak dojmująca, że przyczyniła się do zapamiętania i zachowania nauczania Amosa, w którym jego współcześni i ich potomkowie rozpoznawali zapowiedzi sądu i kary Bożej za występki napiętnowane przez proroka. ${ }^{11}$

$\mathrm{Z}$ zestawienia powyższych informacji nasuwa się jednoznaczny wniosek, że zgodnie z przekonaniami środowiska, w którym dokonano finalnej redakcji Księgi Amosa, prorok działał na początku ostatniej dekady pierwszej połowy VIII w., czyli ok. 760 r. przed Chr.

\section{Tło historyczne nauczania Amosa}

Komentując nagłówek do Księgi Amosa, T. Brzegowy słusznie podkreślił fakt, że „orędzie prorockie dokonywało się zawsze w konkretnych ramach czasowych, przestrzennych i społecznych", ${ }^{12}$ a zatem nie można go prawidłowo zrozumieć bez ich znajomości i respektowania. W komentarzach, monografiach i studiach na temat tej księgi wiele miejsca poświęcano rekonstrukcji „świata duchowego” proroka. ${ }^{13}$ Na pierwszy plan wysuwa się obserwacja, że chociaż Amos

zatrzęsła się straszliwie, rozstąpiły się mury świątyni, zabłysnął w niej blask słońca płomienny i padł na twarz króla, którego natychmiast okrył trąd. W tym samym czasie przed miastem, w miejscu zwanym Eroge, odłupała się połowa zachodniego wzgórza i toczyła się prze cztery stadia, aż zatrzymała się u stóp wzgórza wschodniego, przygniatając drogi i ogrody królewskie"; t e n ż e, Dawne dzieje Izraela. „Antiquitates Judaicae”, Poznań-Warszawa-Lublin 1979, s. 477.

${ }_{10}$ Y. Y a d i n, Hazor, w: E. S t e r n (red.), New Encyclopedia of Archaeological Excavations in the Holy Land, t. 2, Jerusalem, s. 601.

${ }^{11}$ K. J. D e 11, Amos and the Earthquake: Judgment as Natural Disaster, w: A. C. H a g e d o r n, A. M e in (red.), Aspects of Amos. Exegesis and Imagination, Library of Hew Bible/Old Testament Studies 535, New York-London 2011, s. 1-14.

12 T. B r z e g o w y, Czyńcie dobro i kochajcie je! (Księga Amosa), w: t e n ż e i i n., Wielki świat starotestamentalnych proroków, Wprowadzenie w Myśl i Wezwanie Ksiąg Biblijnych 4, Warszawa 2001, s. 48.

13 Zob. H. W. W o $1 \mathrm{ff}$, Amos' geistige Heimat, Wissenschaftliche Monographien zum Alten und Neuen Testament 18, Neukirchen-Vluyn 1964. 
pochodził z królestwa Judy, to działał i nauczał w królestwie Izraela, przede wszystkim w Betel, głównym sanktuarium królewskim państwa północnego, kierując swe nauki do jego mieszkańców.

Biblijna prezentacja dziejów królestwa Izraela jest daleka od obiektywizmu, odzwierciedla bowiem punkt widzenia autorów deuteronomicznego dzieła historycznego, wyraźnie sprzyjającego Jerozolimie i dynastii Dawidowej. ${ }^{14}$ Wpisuje się w wielowiekowe roszczenia do wyłączności w posiadaniu, a nawet w zawłaszczeniu, najstarszego dziedzictwa religijno-narodowego wszystkich Izraelitów. ${ }^{15}$ Analogiczna perspektywa dochodzi do głosu we współczesnych opracowaniach historii starożytnego Izraela, w których dzieje i rola Samarii i jej władców są pomniejszane lub przemilczane. ${ }^{16}$ Pełniejszy i zdecydowanie bardziej obiektywny obraz można nakreślić, uwalniając się od założeń ideologicznych, opierając się przede wszystkim na zachowanych świadectwach pozabiblijnych, zarówno piśmienniczych jak i różnego rodzaju artefaktach. Są to w ogromnej większości źródła asyryjskie, które umożliwiają dobrą znajomość ówczesnej sytuacji i wydatnie uzupełniają, albo korygują, informacje zawarte w Biblii. Wzgląd na to przemawia za potrzebą nawiązania ścisłej i bliskiej współpracy biblistów z asyriologami, ${ }^{17}$ która stanowi warunek sine qua non rzetelnego i wszechstronnego poznawania historii podzielonej monarchii. W ostatnich dekadach asyriologia poczyniła olbrzymie postępy, co znalazło odbicie w dociekaniach

14 Obszernie na jego temat zob. A. d e P u r y, Th. R ö m e r, J.-D. M a c c h i (red.), Israël construit son histoire. L'historiographie deutéronomiste à la lumière des recherché récentes, Le Monde de la Bible 34, Genève 1996.

15 N. N a' $m$ a n, The Israelite-Judahite Struggle for the Patrimony of Ancient Israel, Biblica 91/2010, s. 1-23.

16 Zob. np. M. A v i - Y o n a h, A History of Israel and the Holy Land, Jerusalem 2001, s. 94-96 (przedmowę napisał Szymon Peres).

17 W. C h r o s tow s k i, Asyryjska diaspora Izraelitów jako wyzwanie dla historyków starożytnego Izraela, w: P. M u c h o w s k i, M. M ü n n i c h, Ł. N i e s i o ł o w s k i - S p a n ò, Zachować tożsamość. Starożytny Izrael w obliczu obcych religii i kultur. Materiały z konferencji naukowej, Kazimierz Dolny, 27-29.09.2006, Rozprawy i Studia Biblijne 31, Warszawa 2008, s. 82-97; toż w: Trzecia Świątynia w Jerozolimie i inne studia, Rozprawy i Studia Biblijne 44, Warszawa 2012, s. 38-57. 
historyków starożytnego Izraela i jego religii oraz biblistów, ale w tej dziedzinie jeszcze wiele pozostaje do zrobienia.

W spojrzeniu na historyczny kontekst działalności i nauczania Amosa trzeba dobitnie podkreślić istotne różnice w dziejach królestwa Judy i królestwa Izraela. ${ }^{18}$ Warto wyeksponować kilka z nich. Po pierwsze, geograficzne położenie królestwa Izraela przy ważnych szlakach handlowych spowodowało, że przez niemal cały, ponad dwustuletni, okres istnienia było ono znacznie bardziej włączone w politykę międzynarodową niż królestwo Judy. Po drugie, ludność zamieszkująca terytorium królestwa Izraela zawsze była liczniejsza niż w południowej części podzielonej monarchii. Po trzecie, mimo że Jerozolima już w okresie zjednoczonej monarchii miała status stolicy, natomiast $\mathrm{w}$ pierwszych dekadach królestwo Izraela swojej stolicy nie miało, wojsko, które podczas rozpadu monarchii w większości opowiedziało się za Jeroboamem, założycielem państwa północnego, dało początek prężniejszemu systemowi obrony i zarządzania niż w państwie południowym. Po czwarte, na terytorium Izraela znajdowało się więcej dużych miast niż na terytorium Judy, co sprzyjało rozwojowi procesu urbanizacji w tej części podzielonej monarchii. Znamienne jednak, że zarówno w królestwie Izraela, jak i królestwie Judy miasta, inaczej niż w przypadku starożytnych miast-państw w innych rejonach Bliskiego Wschodu, były podporządkowane prężnej władzy centralnej.

W kontekście tych różnic istniały jednak przesłanki, które przemawiały na korzyść królestwa Judy. Po pierwsze, jej społeczeństwo było o wiele bardziej homogeniczne, skupione wokół Jerozolimy z dość dobrze określonymi granicami naturalnymi. Królestwo Judy tworzyły dwa plemiona - Judy i Beniamina, natomiast królestwo

18 Obszernie zob. np. A. S c ho or s, Die Königreiche Israel und Juda im 8. und 7. Jahrhundert v. Chr. Die assyrische Krise, Biblische Realenzyklopädie 5, Stuttgart-Berlin-Köln 1998; syntetyczny przegląd historii obu części podzielonej monarchii zob. np. S. H. H o r n, P. K y l e M c C a r t e r jr, Podzielona monarchia. Królestwa Judy i Izraela, s. 191-259; na temat chronologii królów Izraela i Judy zob. G. L a r s s o n, The Chronology of the Kings of Israel and Judah as a System, Zeitschrift für Alttestamentliche Wissenschaft 114/2002, s. 224-235. 
Izraela - dziesięć plemion, wśród których nie brakowało tendencji odśrodkowych. Po drugie, a ten czynnik należy postrzegać jako decydujący, w państwie południowym od czasów króla Dawida oraz Salomona, jego syna i następcy na tronie w Jerozolimie, aż do zagłady Jerozolimy przez Babilończyków i utraty niezależności (587) rządzili władcy z jednej dynastii - Dawidowej. ${ }^{19}$ Ciągłość dynastyczna miała ogromne znaczenie dla integralności państwa oraz konsolidacji mieszkańców wokół króla i jego dworu. Sytuacja w państwie południowym była całkowicie inna. W ciągu nieco ponad dwustu lat (930-722) na tronie królewskim zasiadali władcy, którzy nie wywodzili się z dynastii Jeroboama I, twórcy tego państwa. ${ }^{20}$ Historia królestwa Izraela była o wiele bardziej burzliwa, co znalazło wyraz w następujących po sobie zamachach stanu i dochodzeniu do władzy uzurpatorów, którzy mordowali poprzedników i całe ich rodziny. Atmosfera krwawych intryg i ślepej przemocy miała wpływ na powszechne nastroje i przenosiła się na wszystkie warstwy społeczne, powiększając zamęt i dezintegrację społeczeństwa.

Jeroboam II wywodził się $\mathrm{z}$ dynastii założonej przez uzurpatora imieniem Jehu. ${ }^{21}$ Zanim w 841 r. przed Chr. Jehu doszedł do władzy, królestwo Izraela doświadczyło trzech zamachów stanu. Syn Jeroboama I, Nadab (ok. 908-907), został zamordowany przez Baszę, syna Achiasza, który był jednym z wyższych urzędników królewskich (1Krl 15,25-31) i sprawował władzę przez ponad 20 lat (ok. 907-884). Jednak Ela, syn i następca Baszy, po krótkim okresie panowania (ok. 884-883) został zamordowany w pałacu w Tirsie przez Zimriego, wodza rydwanów. Wymordował on rodzinę Baszy, lecz po tygodniu sprawowania władzy popełnił samobójstwo. Jego miejsce - w rezultacie dworskich intryg i zmagań - zajął Omri, sprawny dowódca wojska. Panowanie Omriego (ok. 883-872) przyniosło odnowę Izraela jako potęgi handlowej. Za największe osiągnięcie uznaje się założenie

19 Ich wyliczenie i daty panowania zob. tamże, s. 201.

20 Ich wyliczenie i daty panowania zob. tamże.

${ }^{21}$ Przegląd historii królestwa Izraela w okresie podzielonej monarchii zob. np. w: J. W a r z e c h a, Historia dawnego Izraela, Warszawa 2005, s. 226-317. 
w szóstym roku jego panowania Samarii (1Krl 16,23-24) i uczynienie jej stolicą królestwa Izraela. Wcześniej, czyli przez prawie pół wieku, państwo północne, w odróżnieniu od państwa południowego, nie miało stałej stolicy. Jego władcy rezydowali najpierw w Sychem i Penuel (Jeroboam I), a następnie w Tirsie (1Krl 14,17). Uczynienie z Samarii stolicy państwa północnego sprawiło, że o ile Jerozolima nadal pozostawała centrum królewsko-religijnym, o tyle Samaria od początku pełniła funkcję centrum królewsko-administracyjnego. ${ }^{22}$ Omri stał się założycielem dynastii, która rządziła w Samarii przez ponad 40 lat. Następcą Omriego na tronie był Achab (ok. 872-851), jego syn, a następnie (krótko: 851-850) Ochozjasz, jego wnuk, po czym władzę objął Joram (ok. 850-841). Rzetelna ocena dynastii Omriego (omrydzi) jest o tyle trudna, że nie cieszyła się ona przychylnością środowiska deuteronomicznego, któremu zawdzięczamy biblijną rekonstrukcję dziejów podzielonej monarchii. ${ }^{23} \mathrm{~W}$ sukurs historykom przychodzą źródła asyryjskie i archeologia.

Podczas panowania Jorama jeden $\mathrm{z}$ wysokich rangą dowódców jego wojska, imieniem Jehu, dokonał kolejnego zamachu stanu (2Krl 8,28 - 10,28), zabijając Jorama, a także Ochozjasza, króla Judy. Samaria spłynęła krwią członków dynastii Omriego, co prorok Ozeasz, współczesny Amosowi, określił jako „krew Jezreel” (Oz 1,4). Historiografia biblijna z dużą rezerwą odnosi się do krwawej rebelii Jehu, ale z nieukrywaną satysfakcją wzmiankuje rzeź ,proroków Baala, wszystkich jego wyznawców i wszystkich jego kapłanów" $(2 \mathrm{Krl} 10,19)$. Bunt Jehu nie przyniósł nic dobrego. Przeciwnie, za jego panowania (ok. 841-818) doszło do uszczuplenia państwa północnego w wyniku zajęcia przez Chazaela, króla Damaszku, terytorium położonego na wschód od Jordanu.

Na czas panowania królów z dynastii Omriego oraz Jehu przypadł okres zmagań z Aramejczykami ze stolicą w Damaszku oraz

22 J. K a t z, Jerusalem and Samaria: An Anthropological Tale of Two Cities, Biblical Archaeology Review 40(2014) nr 3, s. 26, 68, 70.

23 Zob. K. S c h n e i d e r, The Omrids: Too Much Theology, Too Little Context, Old Testament Essays 17/2004, s. 267-281. 
odrodzenia Asyrii i wznowienia przez nią imperialnej polityki. Jednym z jej celów stało się podporządkowanie terytoriów położonych na zachód od Mezopotamii, aż po Morze Śródziemne. Po wyprawie Salmanassara III i bitwie pod Qarkar (853), Asyryjczycy wywierali coraz większą presję na Damaszek. Kontynuując politykę parcia na zachód, podjęli zwycięskie kampanie wojenne, w wyniku których Adad-Nirari III (809-782 przed Chr.) podbił i podporządkował sobie terytorium zamieszkane przez Aramejczyków, z Damaszkiem włącznie. Presja Asyrii spowodowała, że pomyślnie dla królestwa Izraela zakończyła się dotkliwa konfrontacja z władcami Damaszku, którzy za panowania Jehu $(2 \mathrm{Krl} 13,5)$ wiele razy stawali do walki z Izraelitami. Władca Asyrii wymusił sowitą daninę od Damaszku, co znacznie osłabiło pozycję jego władców.

Następcą Jehu na tronie w Samarii był Joachaz (ok. 818-802), a po nim Joasz (802-787). Okoliczności, w jakich Jehu doszedł do władzy, mocno rzutowały na panowanie jego następców, naznaczone podejrzliwością i wolą utrzymania się przy władzy. Konfrontacja z Aramejczykami, która spowodowała znaczne osłabienie królestwa Izraela (2Krl 13,3-5), zakończyła się w początkach VIII w. przed Chr., gdy Asyria położyła kres agresywnej polityce Damaszku, podporządkowując go sobie i zmuszając do płacenia regularnej daniny. Ten sam obowiązek dotyczył również Joasza, króla Izraela, inna była jednak motywacja: składanie daniny było traktowane jako wyraz wdzięczności wobec Asyrii, która wybawiła Izraelitów z groźby kolejnych najazdów Aramejczyków. Pokonawszy wojska Ben-Hadada, króla Damaszku, Joasz odzyskał kilka utraconych miast (2Krl 13,25), a nawet rozciągnął swe wpływy na południe, aż po Edom. Gdy pod koniec panowania Adad Nirari III, a później jego następca, byli zajęci wewnętrznymi perturbacjami w Asyrii, królestwo Izraela, uwolnione od ataków najbliższego wschodniego sąsiada, czyli Aramejczyków, mogło się znacznie wzmocnić i rozwijać. Po krótkim oblężeniu Jerozolimy (2Krl 14,8-14) Joasz zdołał podporządkować sobie jej władcę. W tych okolicznościach królestwo Judy stało się wasalem królestwa Izraela, co sprzyjało wzajemnym kontaktom i współpracy. 
Następcą Joasza na tronie w Samarii był Jeroboam II, jego syn, przedostatni władca z dynastii Jehu. Wizerunek króla przekazany w deuteronomicznym dziele historycznym znowu jest daleki od przychylności. Analogicznie jak o pozostałych władcach królestwa Izraela mówi się o nim, że „czynił to, co złe w oczach Pana; nie zerwał z całym grzechem Jeroboama, syna Nebata" (2Krl 14,24). Jednak okres jego długiego panowania należy do najświetniejszych w historii królestwa Izraela. Jeroboam II nie tylko unikał zadrażnień w relacjach z Asyrią, lecz dbał, by były one jak najbardziej poprawne. ${ }^{24}$ Skutecznie zadbał o rozszerzenie i umocnienie granic państwa, ustalając je na obszar od Araby i Morza Martwego po „wejście do Chamat" (2Krl 14,25). ${ }^{25}$ Oznaczało to odzyskanie ziem utraconych za panowania jego poprzedników, czyli Jehu i Joachaza (2Krl 10,32-33; 13,1-9). Co więcej, skierował się ku Zajordaniu, a nawet - przynajmniej na jakiś czas - przejął kontrolę nad Damaszkiem (2Krl 14,28; Am 6,13). Jednym z jego głównych osiągnięć było też odzyskanie pełnej kontroli nad Szlakiem Królewskim, prowadzącym w głąb Półwyspu Arabskiego, oraz nad Via Maris, ważną nadmorską drogą prowadzącą do Egiptu. Sukcesy i ekspansja terytorialna Jeroboama II spotkała się z wielkim uznaniem mieszkańców jego królestwa, co znalazło wyraz w nastawieniu proroka Jonasza, syna Amittaja (2Krl 14,25). Sprzyjająca sytuacja polityczna i okres pomyślności trwał do wstąpienia na tron asyryjski Tiglat-Pilesera III (745-727), ale jego panowanie przypadło na czasy po śmierci Jeroboama II.

Zwycięska konfrontacja z najbliższymi sąsiadami i wzmocnienie pozycji królestwa Izraela stanowiło nową jakość we wzajemnych relacjach. Wszystkie sąsiednie narody wymienione w wyroczniach

${ }^{24}$ Zapewne właśnie tym należy tłumaczyć brak wzmianki o Asyrii w Księdze Amosa, możliwe jest jednak także inne wyjaśnienie, a mianowicie, że wypowiedzi Amosa były przekazywane i zostały utrwalone na piśmie przez Izraelitów w diasporze asyryjskiej; zresztą obie możliwości wcale się nie wykluczają.

25 Polityka Jeroboama II stanowi trzeci etap stopniowej ekspansji terytorialnej królestwa Izraela, której dwie wcześniejsze fazy przypadły na okres pre-omrydzki i omrydzki; zob. I. F in k e l s t e i n, Stages in the Territorial Expansion of the Northern Kingdom, Vetus Testamentum 61/2011, s. 227-242. 
z Am 1,3 - 2,5, a więc Aramejczycy ze stolicą w Damaszku, Filistyni ze stolicą w Gazie, Fenicjanie ze stolicą w Tyrze oraz Edomici, Ammonici i Moabici, a także królestwo Judy, były za rządów Jeroboama II sprzymierzeńcami lub wasalami Izraela. ${ }^{26}$ Ich władców i mieszkańców obowiązywała lojalność wobec Samarii. Znamienne, że słownictwo używane przez proroka, który określa ich występki jako peša, nie ma konotacji moralnych, lecz odnosi się do buntów $\mathrm{z}$ ich strony, postrzeganych jako złamanie lojalności. ${ }^{27}$ Stabilizacja polityczna za panowania Jeroboama II była więc względna i nietrwała, zaś rozmaite przejawy nielojalności sąsiadów zapowiadały kłopoty w nieodległej przyszłości.

Przeobrażenia i zmiany polityczne nie pozostały bez wpływu na sytuację religijną. Podział, który zaistniał po rozpadzie zjednoczonej monarchii (930), rychło skutkował schizmą religijną, która przypieczętowała rozłam i powiększyła wzajemne antagonizmy i niechęć. W deuteronomicznym dziele historycznym, nader oszczędnym w przedstawianiu Jeroboama i pozostałych władców królestwa Izraela, niemało miejsca zajmuje narracja o nowych miejscach kultu, które Jeroboam ustanowił w Betel i Dan (1Krl 12,26-33; 13,1 - 14.18). Eksponując znaczenie Jerozolimy jako jedynego ośrodka prawowitej czci Boga, kładzie się nacisk na centralizację kultu i schizmatycki charakter sanktuariów utworzonych w państwie północnym. Powiększający się podział polityczny z czasem przeobraził się w otwartą konfrontację i zmagania, co rzutowało na pogłębianie schizmy religijnej i stopniowy wzrost rangi Betel i Dan. Sprzyjał temu fakt, że Betel kojarzono z patriarchami Izraela ( $\mathrm{Rdz} 12,8 ; 28,10-22)$, odgrywało więc ono ważną rolę w jego tradycji religijnej. Wielokrotnie potępiany „grzech Jeroboama”, tak w odniesieniu do niego samego, jak i jego następców (1Krl 15,26.34 itd.), polegał nie na wprowadzeniu innej religii, przeciwnej wyznawaniu Boga, lecz ustanowieniu innych niż Jerozolima miejsc kultu, mocno podporządkowanych ideologii królewskiej. Takie same cele wiązali z dwoma sanktuariami na swoim

26 M. A. S w e e n e y, The Twelve Prophets, s. 202.

27 Sh. P a u 1, Amos, Minneapolis 1991, s. 45. 
terytorium władcy państwa północnego. Wraz z założeniem Samarii i wzrostem znaczenia królestwa Izraela rosło więc znaczenie i ranga sanktuariów w Betel i Dan. Nabrały one wyraźnie cech sanktuariów królewskich, które miały uzasadniać i chronić roszczenia do władzy oraz integrować mieszkańców państwa.

\section{Tło spoleczne nauczania Amosa}

Aczkolwiek sytuację za panowania Jeroboama II należy postrzegać w kontekście wcześniejszych, sięgających okresu zjednoczonej monarchii, przeobrażeń i zmian polityczno-społecznych, ${ }^{28}$ to jednak miała specyfikę różniącą ją od tego, co było wcześniej. Wywarło to wielki wpływ na wyłonienie się i okrzepnięcie nowych zjawisk. Wspólnym mianownikiem sytuacji w państwie północnym było wykrystalizowanie się pod wieloma względami nowej struktury społecznej. ${ }^{29}$

Najwyżej w hierarchii stał król i jego rodzina, a także arystokracja nadzorująca posiadłości królewskie i zarządzająca miastami. ${ }^{30}$ Do znacznie większego znaczenia, niż dotąd, doszli rzemieślnicy i wykwalifikowani robotnicy, którzy zajmowali niższą, lecz wpływową pozycję. Najniżej w hierarchii stali rolnicy i pasterze, których głównych źródłem utrzymania były niewielkie uprawy na polach i w ogrodach oraz małe stada owiec i kóz. Trudniąc się uprawą pszenicy, jęczmienia i prosa oraz oliwek, winorośli, fig, sykomor i granatów, wyrabiali niewielkie ilości oliwy i wina, zaspokajające własne

28 R. N o r t h, Social Dynamics from Saul to Jehu, Biblical Theology Bulletin 12/1982, s. 109-119; N. P. L e m c h e, Ancient Israel. A New History of Israelite Society, The Biblical Seminar, Sheffield 1988, s. 130-154; obszernie: M. E. P o 11 e y, Amos and the Davidic Empire, New York-Oxford 1989.

29 W. G. D e v e r, Social Structure in Palestine in the Iron II Period on the Eve of Destruction, w: Th. E. L e v y (red.), The Archaeology of Society in the Holy Land, New York 1989, s. 416-431.

30 Zob. I. J a r u z e $1 \mathrm{~s} \mathrm{k}$ a, Amos and the Officialdom in the Kingdom of Israel. The socio-economic position of the officials in the light of the Biblical, the epigraphic and archaeological Evidence, Poznań 1998. 
potrzeby i wymieniane na inne produkty. ${ }^{31}$ Król sprawował władzę absolutną i wiele wskazuje na to, że traktował poddanych jak sługi, których status był najbliższy statusowi niewolników. ${ }^{32}$

W Księdze Amosa - jak trafnie przypomniał T. Brzegowy - spotykamy się nie tyle z krytyką złego postępowania jednostek, ile „z krytyką społecznych zachowań, w których są zaangażowane całe grupy społeczne". ${ }^{33}$ Rozwarstwienie społeczne było tak głębokie, że sprzyjało piętrzeniu się niesprawiedliwości, skutkującym wykluczaniem oraz dotkliwymi podziałami i antagonizowaniem Izraelitów. ${ }^{34}$ Księga Amosa zawiera wzmianki o urzędnikach królewskich, z których wynika, że dopuszczali się wielu nadużyć. ${ }^{35}$ Napomnienia dotyczące Samarii, zwłaszcza jej bogatych i pozbawionych skrupułów mieszkanek (Am 4,1-3), nie zostawiają wątpliwości, że ich dobrobyt płynął z ograbiania biednej ludności, zobowiązanej do składania wysokich danin. Królestwo Izraela było społecznością wewnętrznie rozdartą, targaną napięciami, które piętrzyły się na skutek wyzysku i krzywdy. Napięcia i konflikty społeczne wzmagały się w okresach nieurodzajów i klęsk żywiołowych, jak np. susza czy choroby zboża, ${ }^{36}$ gdy położenie biednych stawało się jeszcze bardziej dramatyczne.

31 Zwięzłą prezentacje innych aspektów ówczesnego życia codziennego zob. w: S. H. H o r n, P. K y le M c C a r t e r jr, Podzielona monarchia. Królestwa Judy i Izraela, s. 243-245.

32 N. P. L e m c h e, Ancient Israel, s. 152-153.

33 T. B r z e g o w y, Czyńcie dobro i kochajcie je! s. 54.

${ }_{34}$ G. W it a s z e k, Prorocy Amos i Micheasz wobec niesprawiedliwości społecznej, Tuchów 1992; t e n ż e, Niesprawiedliwości społeczne i ich konsekwencje w myśli religijnej proroka Amosa, Tuchów 1992; por. P. K 1 i m e k, Symbolika wykluczenia w Am 2,16, w: K. K i e $\mathrm{t} 1$ i ń s k i (red.), Wykluczenie społeczno-moralne, Inicjatywa Praska Diak. DW-P, Warszawa 2014, s. 53-61.

35 I. J a r u z e l s k a, Royal Officials in the „Book of Amos”, 8th century B. C. An Essay on the Social Theory of the Bible, Rocznik Orientalistyczny 50(1995) nr 1, s. 27-40; t a ż, Urzędnicy królewscy w VIII w. przed Chr. w Księdze proroka Amosa. Szkic z biblijnej teorii społeczeństwa, Poznańskie Studia Teologiczne 8/1998, s. 11-26.

36 Zob. M. S z m aj d z iń s k i, šiddāpon i jērāqon - dwaj mordercy zbożowi w Am 4,9, Studia Lovicensia 12/2010, s. 279-294. 
Ekspansja terytorialna oznaczała rozszerzenie wpływów królestwa Izraela i zintensyfikowanie rozmaitych form wymiany $i$ handlu. Na pierwszy plan, o czym świadczy duża liczba znalezisk ceramicznych, wysuwa się współpraca i ożywiona wymiana handlowa z Fenicją. Na zasięg oraz charakter wymiany i handlu wskazują luksusowe przedmioty odnalezione w Samarii, pochodzące z warstw datowanych na VIII w. przed Chr. Chociaż nie ma całkowitej pewności odnośnie do datowania słynnych wyrobów z kości słoniowej, które - przynajmniej w części - mogą pochodzić z IX w. przed Chr., ${ }^{37}$ to bez wątpienia można je traktować - choćby były odziedziczone - jako potwierdzenie niepospolitej zamożności mieszkańców stolicy za panowania Jeroboama II. ${ }^{38}$ William G. Dever twierdzi, że „stanowią szczególnie wymowne świadectwo rozwarstwienia społecznego w starożytnym Izraelu: po pierwsze, są względnie rzadkie w jakimkolwiek kontekście, tzn. są to prawdziwie luksusowe produkty; po drugie, zostały znalezione nie tylko w stolicy, lecz również w ruinach królewskiego pałacu; i po trzecie, dostarczają jasnych dowodów zarówno wyrafinowanego smaku «egzotycznego» wyposażenia obcego pochodzenia, jak i sposobów nabywania takich kosztowności" ${ }^{39} \mathrm{Na}$ to samo wskazują znaleziska epigraficzne, wśród nich ostraka znalezione w 1904 r. podczas prac wykopaliskowych w Samarii. Datowane na okres od dziewiątego do siedemnastego roku panowania króla, którego imienia nie podają, najpewniej Jeroboama II, czyli lata 779-771, wyszczególniają rozmaite rodzaje produktów rolniczych i ogrodniczych, wskazując na mocne powiązania właścicieli ziemskich z dworem królewskim. Księga Amosa potwierdza, że w połowie VIII w. przed Chr. w królestwie Izraela istniała warstwa zamożnych oraz wpływowych właścicieli ziemskich

37 Sugeruje to wzmianka w 1Krl 22,39, dotycząca pałacu króla Achaba.

38 E. F e r r is B e c h, The Samaria Ivories, Marzeah, and Biblical Text, Biblical Archaeologist 56/1993, s. 94-104.

${ }^{39}$ Cyt. za: S. H. Hor n, P. Ky le M c Carter jr, Podzielona monarchia. Królestwa Judy i Izraela, s. 238. 
i bogaczy, których, we współczesnym nazewnictwie, można określić mianem oligarchów.

Nasilenie kontaktów handlowych, poszerzenie granic państwa i wzrost zamożności warstw rządzących miało wiele negatywnych skutków. Trzeba było się poważnie liczyć, podkreślał Amos $(6,14)$, z nieprzychylną reakcją sąsiadów Izraela, co wymagało stałego zwiększania nakładów na obronność i utrzymywania w pogotowiu dużej liczby wojska. Nowe terytoria przyłączone do państwa północnego, a także rozwój rolnictwa i sadownictwa były związane z królewskimi przydziałami gruntu dla zwolenników władcy. Intensywna działalność rolnicza, sadownicza i handlowa mieszkańców królestwa Izraela spowodowała znaczący wzrost wpływów z podatków i danin wnoszonych na dwór królewski. Istnieje wiele przesłanek, potwierdzających wypowiedzi Amosa (6,4-6), z których wynika, że standard życia dworu i bogaczy z nim związanych upodabniał ich do sybarytów zamkniętych w sobie i nieczułych na potrzeby innych.

Potwierdzeniem pomyślności był bujny rozkwit miast. W tej dziedzinie rozstrzygające światło rzuca nie Biblia czy pisane źródła pozabiblijne, lecz archeologia, która najwierniej obrazuje stan kultury materialnej w królestwie Izraela w fazie żelaza IIb, czyli za panowania Jeroboama II. ${ }^{40} \mathrm{Na}$ jego terytorium podjęto wiele zakrojonych na dużą skalę przedsięwzięć budowlanych, które polegały nie tyle na zakładaniu nowych miast, ile modyfikowaniu, rozbudowywaniu i umacnianiu tych, które już istniały (Chasor, Megiddo, Dan). Sprzyjało to pozyskiwaniu lokalnej ludności i włączaniu jej w realizację odgórnej polityki urbanizacyjnej. Archeolodzy podkreślają aspekt starannego planowania przestrzennego miast, uporządkowania ich dzielnic i wzmacniania murów obronnych. Miarą sukcesów Jeroboama II stało się głównie rozbudowanie i umocnienie Samarii, stolicy kraju. Okres pokoju sprzyjał także wzrostowi demograficznemu.

40 G. B a r k a y, The Iron Age II-III, w: A. B e n -T o r (red.), Archaeology of Ancient Israel, New Haven-London 1992, s. 302-373; zob. również rozdział Samaria $w$ świetle archeologii, w: A. P a r r o t, Wśród zabytków Samarii i Jerozolimy, Warszawa 1971, s. 36-56. 
Liczba ludności w królestwie Izraela powiększała się znacznie szybciej niż w królestwie Judy, osiągając pod koniec panowania Jeroboama II ponad 200 tys. mieszkańców.

Sytuacja społeczna w królestwie Izraela miała jednak również drugi biegun. Daniny wnoszone na rzecz króla i jego dworu zbierano kolektywnie, czyli określano ich wysokość i nakładano je na poszczególne wspólnoty, to jest miasta, osady i wsie. Już na poziomie odgórnych decyzji dotyczących ich wysokości nie brakowało rozmaitych nadużyć, z korupcją na czele. Podczas gdy jedne wspólnoty, w których bogaci mieli dużo do powiedzenia, unikały odpowiednio wysokich należności, inne, znacznie biedniejsze i nie mające wpływów, były okładane podatkami przerastającymi ich możliwości. Taki sam proceder miał miejsce na poziomie poszczególnych wspólnot. Gdy należało ustalić wysokość daniny wnoszonej przez członków wspólnoty, co odbywało się „,w bramie” (Am 5,11-14), wtedy ludzie bogaci i wpływowi pomniejszali swoje należności, przerzucając na barki ubogich ciężar danin przekazywanych władcy. Wyrządzane krzywdy były ogromne, ponieważ nasilała się bezkarność, której przejawem było fałszowanie wagi i miar. Ubodzy, pozbawieni możliwości skutecznej obrony, musieli się zapożyczać, a nawet wyzbywać swojej własności, co prowadziło ich do ruiny, a powiększało stan posiadania i dobrobyt zamożnych. Łamanie zasad sprawiedliwości społecznej i perwersja w stosowaniu prawa $(5,7.10 .12)$ powiększały ciężkie położenie i potęgowały rozpacz ubogich $(5,9.11)$.

Redystrybucja gruntów, której zasady były dalekie od sprawiedliwości społecznej, oraz gwałtownie narastający nierówny podział dóbr skutkowały postępującym rozwarstwieniem społeczeństwa. W miastach i wsiach na terenie całego kraju stale rosła liczba ludzi biednych i coraz bardziej zadłużonych. Zadłużenie, z którego nie mogli wyjść, przyczyniało się do wzrostu liczby niewolników i służących, zdanych na łaskę i niełaskę wierzycieli, u których zaciągnęli długi. W Księdze Amosa nie ma żadnych wzmianek o przybyszach ani ubogich, wdowach i sierotach, którym należało nieść pomoc. 
Jego napomnienia są kierowane pod adresem władcy i sojuszników. ${ }^{41}$ Wypowiedzi proroka świadczą, że ci, w których obronie stawał, wcześniej nie byli niewolnikami. Ich bieda była spowodowana krzywdami, których doznali, m.in. koniecznością płacenia wysokich danin w zbożu i winie..$^{42}$ Posiadacze kawałków gruntu, poletek z drzewami oliwnymi i niewielkich winnic, których byli pełnoprawnymi właścicielami, zostali zmuszeni do wyzbywania się własności oraz skazani na żebranie i biedę. Będąc pełnoprawnymi obywatelami, zdolnymi do działań prawnych, doznawali krzywd „w bramie” $(5,13)$, czyli podczas sprawowania sądów. Niesprawiedliwi i przekupni sędziowie wydawali krzywdzące wyroki, pozbawiając ubogich podsądnych majątku i godności, co godziło w integralność Izraela.

Pogarszająca się sytuacja społeczna nie pozostała bez wpływu na wiarę i pobożność Izraelitów. Dobrobyt stosunkowo niewielkiej, lecz mającej duże możliwości oddziaływania klasy bogaczy sprzyjał otwarciu na wpływy i tendencje kulturowe i religijne pochodzące z zewnątrz, zwłaszcza z terenów położonych na północ od królestwa Izraela, czyli Fenicji. Rozpowszechniony tam kult Baala, bóstwa współżycia płciowego, polegający na promowaniu swobody seksualnej, był dla wielu bogatych Izraelitów bardziej atrakcyjny niż religia monoteistyczna z jej surowymi wymaganiami etycznymi. Przenikanie rozmaitych form obcych kultów docierało do Samarii, a także do Jerozolimy. Na ostrakach z Samarii rozpoznano dużą liczbę imion osobowych z teoforycznym pierwiastkiem yaw-, potwierdzającym kult Jahwe, oraz $b a^{\prime} l$, wskazującym na kult Baala. Ich wzajemna relacja wynosi w przybliżeniu $11: 7 .^{43}$ To, że druga grupa może też

${ }^{41}$ I. J a r u z e 1 s k a, Amos i Ozeasz wobec królów Izraela, w: I. S k u p i ń s k a -L o v s e t, P. N o w o g ó r s k i (red.), Starożytna Palestyna w badaniach polskich, Łódź 2003, s. 33-46.

${ }^{42}$ Por. M. Szmajdziński, Opis ucisku ubogich w Am 2,6-8, w: W. Ch r o s t o w s k i (red.), „Pieśniami dla mnie Twoje przykazania”. Księga pamiątkowa dla Księdza Profesora Janusza Frankowskiego w 50. rocznicę święceń kapłańskich i 75. rocznicę urodzin, Warszawa 2003, s. 302-329.

43 W. F. A 1 b r i g h t, Archaeology and Religion of Israel, Anchor Books, Garden City 1969, s. 155. 
odnosić się do Jahwe, wzywanego jako Baal, czyli Pan, nie tylko nie zmienia obrazu na lepsze, ale - przeciwnie - wskazuje, jak daleko posunęła się erozja wiary i podatność na groźny synkretyzm religijny. Co się tyczy Jerozolimy, w deuteronomicznym dziele historycznym znajdujemy mocne potępienia obcych wpływów religijnych, nawiązania do napięć między wyznawcami Jahwe i czcicielami Baala $(1 \mathrm{Krl}$ 18,16-40) oraz wyraźną pochwałę zniszczenia świątyni Baala wzniesionej za panowania Atalii (2Krl 11,8). Podporządkowanie Szlaku Królewskiego skutkowało, na co wskazują znaleziska z Kuntillet Ajrud, ${ }^{44}$ oddziaływaniu politycznemu, kulturowemu i religijnemu Samarii na terytoria położone na południe od królestwa Judy. ${ }^{45}$

Nadużycia ekonomiczne i społeczne musiały wywoływać napięcia i konflikty oraz reakcję tych, którzy je dostrzegali i potępiali. Prorok Amos, uważnie obserwując ówczesne wydarzenia, bezkompromisowo ukazywał negatywne konsekwencje gwałtownego rozwoju ekonomicznego i gospodarczego (2,6-8; 4,1-3; 5,10-12; 6,4 - 7,11-14; 8,4-6). Jest pierwszym prorokiem, który wystąpił z tak bezkompromisową i radykalną krytyką niesprawiedliwego porządku ekonomicznego i społecznego. Gwałtowność jego wystąpień i nauczania wynikała z rozdźwięku, jaki istniał między jego świadomością o powołaniu i charyzmatycznym uzdolnieniu przez Boga a marazmem i bezczynnością urzędowego kapłaństwa i kłamstwami mnożonymi przez fałszywych proroków, którzy, będąc na usługach króla i jego zwolenników, korzystali z różnych dobrodziejstw, które dawało im ich uprzywilejowane położenie. ${ }^{46}$

44 Zob. S. H. Hor n, P. Ky le M c C a r te r jr, Podzielona monarchia. Królestwa Judy i Izraela, s. 231-234.

45 Ph. J. K i n g, Amos, Hosea, Micah: An Archaeological Commentary, Philadelphia 1988, s. 104-106.

46 Zob. H. Graf R e vet low, Das Amt des Propheten bei Amos, Forschungen zur Religion und Literatur des Alten and Neuen Testament 80, Göttingen 1962; G. M. Tu c k e r, Prophetic Authority, Interpretation 21-1979, s. 423-434; W. C h r o s t o w s k i, Konflikt kapłana Amazjasza z prorokiem Amosem (Am 7,10-17). Przypadek czy prawidłowość? w: D. D z i a d o s z (red.), Od Melchizedeka do Jezusa-Arcykapłana. Biblia o kapłaństwie, Analecta Biblica Lublinensia V, 
W ścisłym związku z problematyką społeczną pozostawały sprawy kultu. ${ }^{47}$ Amos dobrze znał nadużycia popełniane w sanktuarium w Betel. Wprawdzie pochodził z Tekoa, na południe od Jerozolimy, był więc zobowiązany do składania ofiar w świątyni jerozolimskiej, jednak w jego czasach Ozjasz, król Judy, był wasalem Jeroboama II, króla Izraela. Wydaje się prawdopodobne, że Amos mógł być przedstawicielem reprezentacji mieszkańców państwa południowego przynoszących należne ofiary i daniny na rzecz Jeroboama II do królewskiego sanktuarium w Betel.$^{48}$ Historycy zwracają uwagę, że Ozjasz, król Judy, wiele uwagi poświęcał rolnictwu i sadownictwu oraz wyposażeniu wojska. Jego polityka mogła być spowodowana naciskami ze strony Jeroboama II, który domagał się dokładnego wypełniania zobowiązań ekonomicznych, oraz podejmowanymi na własną rękę dyskretnymi przygotowaniami do zrzucenia z siebie uciążliwego jarzma podległości i danin.

Nadużycia popełniane przez bogatych miały być w ich zamyśle kompensowane przez zewnętrzne oznaki pobożności. Sanktuaria w Dan i Betel, zbudowane w konfrontacji ze świątynią w Jerozolimie, stały się celem częstych pielgrzymek. Nie chodziło jednak o oddawanie czci Bogu, lecz usprawiedliwianie siebie i swego postępowania. Składane ofiary miały zadośćuczynić przemocy i niesprawiedliwości, ale nie na drodze zaniechania tego, co złe, lecz pozyskiwania przychylności i aprobaty kapłanów pozyskiwanych w celu przymykania oczu na rażący wyzysk i krzywdy. Szczególne znaczenie miały „rogi”

Lublin 2010, s. 59-71; toż w: t e n ż e, Trzecia Świątynia w Jerozolimie i inne studia, Rozprawy i Studia Biblijne 44, Warszawa 2012, s. 229-243.

47 Por. T. B rzegow y, Prorocy Amos $i$ Ozeasz $w$ walce o czysty kult, w: W. C h r o s t o w s k i (red.), Dzieci jednego Boga. Praca zbiorowa uczestników seminarium naukowego w Spertus College of Judaica w Chicago (1989), Kośció1 a Żydzi i Judaizm 2, Warszawa 1991, s. 95-127.

48 Tak sugeruje M. A. S w e e n e y, The Twelve Prophets, s. 197. Na potwierdzenie przytacza określanie Amosa mianem nōqēd, które w nawiązaniu do analogicznego określenia na steli Meszy, króla Moabu, wskazuje na jego rangę jako przywódcy, lub przynajmniej nadzorcy, urzędowej reprezentacji z państwa południowego do sanktuarium w Betel. 
ołtarza, wyrażające jego świętość i namaszczane krwią zwierząt ofiarnych. Dotarcie do nich i ich uchwycenie zapewniało ochronę przed mścicielem krwi i każdym, kto czyhał na życie lub zdrowie uciekiniera. Dramatyczne położenie wielu biednych, doprowadzonych na skraj rozpaczy, rodziło w nich żądzę odwetu i zemsty na krzywdzicielach. W takich przypadkach ich obecność w Dan i Betel miała być zabezpieczeniem ich bezkarności. Niezwykle surowe potępienia Amosa, który pogardliwie określa Betel jako „Bet Awen”, 49 podkreślają z jednej strony przepaść między fałszywą a prawdziwą religijnością, a z drugiej wzywają do radykalnej naprawy postępowania, tak by pielgrzymowanie do sanktuarium odzyskało właściwe znaczenie i sens (5,14-15.21-23).

Daleko idące konsekwencje dla życia religijnego miała pogarszająca się sytuacja ludzi ubogich. Ubóstwo materialne, któremu towarzyszyło poczucie beznadziejności i rozpacz, prowadziły do narastającego ubóstwa duchowego. Chociaż Amos nie wyjaśnia, kim jest „ojciec i syn, którzy chodzą do tej samej dziewczyny” (Am 2,7), wydaje się niemal pewne, że ma na myśli biednych, którzy w klimacie szeroko rozpowszechnionej prostytucji nie zważali na żadne normy moralne. ${ }^{50}$ Baalizacja ich postępowania poszła tak daleko, że zatracili poczucie wstydu. W ten sposób nakręcała się spirala dewiacji społecznych i religijnych, które prowadziły do zepsucia narodu, skutkując chaosem, konfliktami i zobojętnieniem religijnym. Ortodoksja zeszła na daleki plan w warunkach, gdy zepsute życie i postępowanie szukało dla siebie usprawiedliwienia, zaś wyznawcy Boga, bogaci i biedni, żyli tak, że lepiej dla nich, by nie przypominano im moralnych powinności.

Bilansując sytuację za panowania Jeroboama II oraz okoliczności nauczania proroka Amosa, Michał Peter napisał: „Upajano

49 E. A. K n a u f, Beth Aven, Biblica 65/1984, s. 251-253.

50 Inne wyjaśnienie, dopatrujące się tu nazwy miejscowości w pobliżu Jerycha, zob. Sh. M o u g h t i n - N u m b y, „A Man and his Father go to Naarah in Order to Defile My Holy Name!' Rereading of Amos 2,6-8, w: A. C. H a g e d o r n, A. M e i n (red.), Aspects of Amos, s. 59-82. 
się chwilowym bezpieczeństwem i zamożnością, kontentując się zewnętrzną poprawnością $\mathrm{w}$ ceremoniale religijnym, zaprawionym sporą przymieszką pogaństwa i zabobonu. Tak to często nastaje cisza przed burzą, poczucie bezpieczeństwa przed zagładą. Zarodki jej widział proroczym okiem natchniony Amos, dlatego w gwałtownych, pełnych ognia słowach domaga się sprawiedliwości w stosunkach społecznych, w sądach i handlu. Woła o religię serca i duszy, krytycznie oceniając wzrost ofiar i pielgrzymek". ${ }^{51}$ Profetyczna funkcja proroka polegała na tym, że dokonywał religijnej oceny teraźniejszości z myślą o poprawnym kształtowaniu przyszłości.

\section{Od orędzia proroka do Księgi Amosa}

Słusznie podkreśla się, że „Amos jest pierwszym «prorokiem klasycznym», pierwszym, którego wyrocznie dotarły do nas w postaci księgi". ${ }^{22}$ Trwają jednak dyskusje odnośnie do czasu jej opracowania w kształcie, w którym weszła do kanonu ksiąg świętych. ${ }^{53}$ Zróżnicowanie zapatrywań i poglądów jest ogromne. Zaniechano dawnego spojrzenia, datującego integralnie Księgę Amosa na VIII w. przed Chr., przedkładając inne propozycje.

Przykładowo, Th. Lescow wskazywał na trzy fazy kompozycji Księgi Amosa, które miały miejsce przed wygnaniem babilońskim, oraz czwartą, która nastąpiła po powrocie z wygnania. Faza pierwsza obejmuje działalność i nauczanie Amosa, druga to podjęta ok. 680 r. przed Chr. reinterpretacja dokonana w świetle zagłady Samarii i królestwa Izraela, zaś trzecia polegała na powtórnej reinterpretacji

51 M. P e t e r, Dzieje Izraela, Biblioteka Pomocy Naukowych 11, Poznań 1996, s. 70; por. G. W it a s z e k, Amos z Tekoa, prorok przyszłości, Ruch Biblijny i Liturgiczny 44(1991) nr 1-3, s. 18-25.

${ }_{52}$ M. L. B a r ré, Księga Amosa, w: R. E. B row n, J. A. F it z m y e r, R. E. Mu r p h y (red. nauk.), W. C h r o s t ow s k i (red. nauk. wyd. pol.), Katolicki komentarz biblijny, Prymasowska Seria Biblijna 17, Warszawa 2001, s. 823.

53 Zob. np. V. M a a g, Text, Wortschatz und Begriffswelt des Buches Amos, Leiden 1951; J. D. W. W a t t s, The Origin of the Book of Amos, Expository Times 66/1954-55, s. 109-112. 
i aktualizacji dokonanej na potrzeby polemiki z polityką prowadzoną przez judzkiego króla Manassesa, a po nim króla Jojakima. Upadek Jerozolimy i zburzenie świątyni sprawiły, że zagłada Samarii była przedstawiana jako antycypacja losu Jerozolimy. ${ }^{54}$ Czwarta faza kompozycji przypadła na $\mathrm{V}$ w. przed $\mathrm{Chr}$. i jej celem było promowanie wyłączności kultu sprawowanego w świątyni jerozolimskiej oraz polemika antysamarytańska. ${ }^{55}$

Analogicznie G. Hamborg również sugeruje cztery fazy kompozycji Księgi Amosa, ale wyszczególnia je inaczej: pierwsza miała miejsce wkrótce po 722 r., druga nastąpiła przed wygnaniem babilońskim, trzecia w okresie wygnania babilońskiego, a czwartą należy datować na okres powygnaniowy. ${ }^{56}$ Dwie pierwsze fazy zaowocowały zebraniem i uporządkowaniem nauczania proroka Amosa, natomiast dwie pozostałe - jego aktualizowaniem i finalnym opracowaniem.

Co się tyczy datowania ostatecznej redakcji Księgi Amosa, umieszczanej w okresie po powrocie $\mathrm{z}$ wygnania, poglądy uczonych są dalekie od zgody. Jedni, jak Th. Lescow czy Ph. R. Davies, ${ }^{57}$ sytuują ją w połowie V w. przed Chr., dopatrując się intencji uprawomocnienia roszczeń Judy i świątyni jerozolimskiej, niezbędnego w sytuacji konfrontacji z Samarytanami i konsolidacji wyłaniającej się żydowskiej samoświadomości. Wzgląd na zagładę Samarii, która nie została odbudowana, a także upadek królestwa Izraela, które się nie podniosło, traktowano jako argument na korzyść Jerozolimy i Judy, które odrodziły się w okresie perskim. Nauczanie Amosa,

54 Th. L e s c o w, Das vorexilische Amos, Erwägung zur seiner Kompositionsgeschichte, Biblische Notizien 93/1998, s. 23-55.

${ }_{55}$ Te n ż e, Das nachexilische Amosbuch. Erwägungen zu seiner Kompositionsgeschichte, Biblische Notizien 99/1999, s. 69-101.

56 G. H a m b o r g, The Post-722 and Late-Pre-Exilic Compositions Underlying the Amos-Text, w: R. P. G o r d o n, H. B a r s t a d (red.), ,Thus Speaks Ishtar of Arbela". Prophecy in Israel, Assyria and Egypt in the Neo-Assyrian Period, Winona Lake (IN) 2013, s. 143-159.

${ }^{57}$ Ph. R. D avi e s, Why Do We Know About Amos? w: D. V. E d e $1 \mathrm{~m}$ a n, E. B e n Zvi (red.), The Production of Prophecy: Constructing Prophecy and Prophets in Yehud, Bible World, London-Oakville (CT) 2009, s. 55-72. 
wskazującego na przyczyny nieszczęść, z jednej strony odbierano jako potwierdzenie uprzywilejowanej pozycji Jerozolimy, a z drugiej stanowiło ono poważne ostrzeżenie przed popełnianiem podobnych wykroczeń i przestępstw.

Inni komentatorzy Księgi Amosa, jak np. Ch. Levin, ${ }^{58}$ przesuwają jej ostateczną redakcję dopiero na III w. przed Chr. Co więcej, Ch. Levin twierdzi, że rozmaite aspekty krytyki społecznej, zawartej w Am 2,6-8; 4,1-2; 5,12b i 8,4-8, nie przystają do kontekstu VIII w. przed Chr., odzwierciedlając uwarunkowania ekonomiczne i religijne okresu perskiego i hellenistycznego. Jego zdaniem, właśnie na takim gruncie należy umiejscowić finalną rewizję tekstu Księgi Amosa.

Stanowisko Ch. Levina jest całkowicie odosobnione i wręcz kuriozalne. Nagłówek Księgi Amosa (1,1), podobnie jak nagłówki kilku innych ksiąg prorockich (Iz, Jr, Oz, Mi, So), w których rozpoznajemy synchronizację panowania królów Judy i Izraela typową dla redakcji deuteronomicznej, przemawiają za tym, że gruntownej redakcji księgi dokonano właśnie w tym środowisku. Świadczą o tym także rozpoznane w księdze liczne dodatki deuteronomiczne. ${ }^{59}$ Tym uzasadniano pogląd, że Księga Amosa przybrała ostateczny kształt podczas wygnania babilońskiego, czyli w VI w. przed Chr. ${ }^{60}$ Potwierdzenia (mocno dyskusyjnego!) miałyby dostarczać wyrocznie przeciw narodom w Am 1-2, w których W. Schütte dopatruje się spojrzenia właściwego dla wygnańców z Jerozolimy i Judy. ${ }^{61}$ Tak czy inaczej, wiele przemawia za tym, że pamięć o działalności i nauczaniu proroka Amosa, zanim została utrwalona na piśmie, miała długie dzieje przedliterackie. Jeżeli chodzi o jej decydującą redakcję, przypadła ona na czas wygnania babilońskiego, po czym - zapewne

58 Ch. L e vi n, Das Amosbuch der Anavim, Zeitschrift für Theologie und Kirche 94/1997, s. 407-436.

${ }_{59}$ Ponad pół wieku temu podkreślał to W. H. S c h m i d t, Die deuteronomistische Bearbeitung des Amosbuches, Zeitschrift für Alttestamentliche Wissenschaft 77/1965, s. 168-193.

${ }^{60}$ J. St. S y n o w i e c, Prorocy Izraela, ich pisma i nauka, Kraków 1995, s. 114.

${ }_{61} \mathrm{~W} . \mathrm{S}$ c h ü t t e, Israels Exil in Juda Und die Völkersprüche in Am 1-2, Biblica 92/2011, s. 528-553. 
w samych początkach okresu perskiego (539-333) - proces adaptacji i aktualizacji orędzia proroka z VIII w. przed Chr. definitywnie się skończył. Konkluzja brzmi: Księga Amosa w swej kanonicznej postaci wykazuje wpływy wydarzeń zarówno z kontekstu 722, jak i 587 r. przed Chr.

Mimo że kompozycja Księgi Amosa trwała dość długo, to jednak nadzwyczaj wiernie ukazuje ona obraz sytuacji politycznej, społecznej i religijnej z połowy VIII w. przed Chr. Wbrew pochopnej i pozbawionej uzasadnienia opinii Ch. Levina, odzwierciedla nastroje panujące wśród mieszkańców królestwa Izraela niedługo przed jego upadkiem. Poglądy, które to negują, pozostają jedynie w sferze teoretycznych domysłów i hipotez. Pojawiła się sugestia, że orędzie zawarte w księdze, np. wypowiedź w Am 6,2 i inne, mieszczą się w obrębie VIII w. przed Chr., lecz pasują do okoliczności związanych z wyprawami Tiglat-Pilesera III do Syrii i Palestyny, a więc pochodzą z okresu między 738 a 732 r. przed Chr. ${ }^{62}$ Jednak nie widać żadnych przekonujących podstaw do przesuwania kontekstu działalności proroka na burzliwe dekady po śmierci Jeroboama II.

Księga Amosa stanowi wieloaspektowe odbicie kontekstu społecznego, kulturowego, ekonomicznego i religijnego za jego panowania. ${ }^{63}$ „Amos jest konkretny i wyrazisty w swoich opisach; jego redaktor jest twórczy, refleksyjny, kompleksowy i logiczny". ${ }^{64}$ Obraz sytuacji w królestwie Izraela, która poprzedziła jego klęskę, zawarty w Księdze Amosa jest zgodny z jego stanem rzeczywistym. Znamy go dobrze głównie dzięki zachowanym źródłom asyryjskim, które jednoznacznie potwierdzają niestabilność polityczną, ogromne problemy ekonomiczne, napięcia wewnątrz plemienne oraz złą politykę

${ }^{62}$ P. D. F. S t rij d o m, Reappraising the Historical Context of Amos, Old Testament Essays 24/2011, s. 221-254.

${ }_{63}$ M. H a r a n, The Historical Background of the Prophecies of Amos, w: Ch. C o he $\mathrm{n}$ i in., Birkat Shalom. Studies in the Bible, Ancient Near Eastern Literature, and Postbiblical Judaism Presented to Shalom M. Paul on the Occasion of His Seventieth Birthday, Winona Lake (IN) 2008, s. 251-259.

${ }^{64}$ B. P e c k h a m, History and Prophecy. The Development of Late Judean Literary Traditions, New York 1993, s. 170. 
międzynarodową ${ }^{65}$ Nauczania zachowanego w Księdze Amosa wcale nie musimy traktować jako vaticinia ex eventu, ponieważ uważna obserwacja ówczesnej sytuacji i narastających napięć skłaniały do wniosku, że bieg wydarzeń, mimo oznak pomyślności za panowania Jeroboama II, przybierał coraz bardziej dramatyczny obrót. ${ }^{66}$ Wnikliwa analiza różnych fragmentów księgi (np. Am 2,8; 4,1-3; 6,4-7), ilustrujących proces alienacji społecznej i kulturowej z początku drugiej połowy VIII w. przed Chr., świadczy, że Amos znał sytuację warstwy ubożejących wieśniaków i był z nimi solidarny. ${ }^{67}$

Pozostaje odpowiedzieć na pytanie, gdzie i w jakich okolicznościach pamięć o Amosie oraz jego działalności i nauczaniu przetrwała przez około dwa stulecia, które upłynęły między połową VIII a VI w. przed Chr. Mogła być ona, jak zwykło się powszechnie przyjmować, przekazywana w królestwie południowym, ${ }^{68}$ ale $\mathrm{w}$ gruncie rzeczy nie ma przekonujących dowodów, że tak się stało. Znacznie bardziej prawdopodobne, że została zachowana w środowisku asyryjskiej diaspory Izraelitów. Zaistniawszy pod koniec VIII w. przed Chr., po wcześniejszych deportacjach ok. 50 tys. mieszkańców państwa północnego do Mezopotamii, z początkiem następnego stulecia okrzepła, a deportowani i ich potomkowie zadbali o zachowanie wiary i tradycji przyniesionych z ojczyzny. Druzgocące doświadczenie zagłady Samarii i królestwa Izraela oraz utraty ziemi, przymusowych

65 P. D u b o v s k y, Why Did the Northern Kingdom Fall According to 2Kings 15? Biblica 85/2014, s. 321-346.

${ }^{66}$ A. S c h e r e r, Vom Sinn prophetischer Gerichtsverkündigung bei Amos und Hosea, Biblica 86/2005, s. 1-9.

${ }_{67}$ H. R e i m e r, Essen und Trinken am Pranger (Amos), w: M. G e i g e r, Ch. M a i e r, V. S c h m i d t (red.), Essen und Trinken in der Bibel. Ein literarisches Festmahl für Rainer Kessler zum 65. Geburtstag, Güterloh 2009, s. 362-373.

${ }_{68}$ Na jego terenie, o czym świadczy też nagły wzrost populacji Jerozolimy, pod koniec VIII w. przed Chr. osiedliło się wiele tysięcy uciekinierów z królestwa Izraela. Nie widać jednak żadnych oznak, aby ich przybycie miało znaczący wpływ na ożywienie religii i pobożności mieszkańców królestwa Judy. Co więcej, panowanie Manassesa nie sprzyjało zachowaniu przyniesionych tradycji religijnych. 
przesiedleń i wygnania potwierdziło prawdziwość słów Amosa, sprawiając, że nadal zachowywały one aktualność. ${ }^{69}$

W sytuacji diaspory dawne nauczanie nabierało nowego znaczenia, było więc aktualizowane i adaptowane do zmienionych okoliczności. W Księdze Amosa rozpoznajemy motywy znane z innych ksiąg biblijnych oraz mające odpowiedniki w kulturze i wierzeniach okresu nowoasyryjskiego. Do takich należy np. motyw niemożliwości ucieczki i nieuniknionej kary w Am 9,1-4, który ma analogię, bądź źródło, w tekście zachowanym na tzw. pryzmie Esarhaddona. ${ }^{70}$ Jeżeli jest to analogia, można w niej upatrywać potwierdzenie kulturowych wpływów asyryjskich w królestwie Izraela jeszcze przed niszczycielskimi najazdami i deportacjami, które położyły kres jego istnieniu. Natomiast jeżeli jest to źródło, zatem tego rodzaju wpływy dały o sobie znać przede wszystkim w warunkach asyryjskiej diaspory Izraelitów w Mezopotamii. Brak nawet jednej wyraźnej wzmianki o Asyrii, która dokonała zagłady królestwa Izraela, bywa interpretowany jako argument, że księga odzwierciedla czasy późniejsze. ${ }^{71}$ Można jednak ów brak wyjaśnić inaczej: zasadnicze opracowanie orędzia Amosa nastąpiło w środowisku asyryjskiej diaspory Izraelitów, w którym unikano nastawienia antyasyryjskiego, ponieważ mogło ściągnąć kolejne bolesne konsekwencje. W sytuacji przechodzenia od wygnania do diaspory przydatne również były prorockie potępienia niesprawiedliwości społecznych, które w lokalnych wspólnotach wygnańców mogły się znowu powtórzyć. Ta okoliczność wydatnie

${ }^{69}$ R. de Menezes, Księga Amosa, w: W. R. Far me r (red. nauk.), W. C h r o s t o w s k i (red. nauk. wyd. pol.), Międzynarodowy komentarz do Pisma Świętego. Komentarz katolicki i ekumeniczny na XXI wiek, Warszawa 2001, s. 1011.

${ }^{70} \mathrm{H}$. I r s i g l e r, Keine Flucht vor Gott. Zur Verwendung mythischer Motive in der Rede vom richterlichen Gott in Amos 9,1-4 und Psalm 139, w: t e n ż e (red.), Mythisches in Prophetie und Psalmen, Quaestiones Disputatae 209, Freiburg-Basel-Vienna 2004, s. 184-233.

${ }^{71}$ J. Ch. Gertz, Die unbedingte Gerichtsankündigung des Amos, w: F. S e d $1 \mathrm{~m}$ e i e r (red.), Gottes Wege suchend. Beiträge zum Verständnis der Bibel und ihrer Botschaft. Festschrift für Rudolf Mosis zum 70. Geburtstag, Würzburg 2003, s. 153-170. 
przyczyniła się do tego, że nauczanie proroka zostało wiernie zachowane, jako jeden $\mathrm{z}$ fundamentów zachowania tożsamości z dala od ojczyzny.

Z początkiem VI w. przed Chr. do potomków wygnańców z dawnego królestwa Izraela dołączyły liczebnie znacznie mniejsze, ale kulturowo i religijnie wyraziście ukształtowane, grupy wygnańców z królestwa Judy. Babilońska polityka deportacyjna miała bardzo wiele wspólnego z polityką prowadzoną przez Asyryjczyków. ${ }^{72}$ Jedni i drudzy stosowali starannie zaprogramowaną strategię, która miała cztery cechy. Po pierwsze, z podbitego terytorium nie uprowadzano całej populacji, lecz jej część. Po drugie, w nowych warunkach deportowani nie byli wyniszczani ani traktowani jak niewolnicy. Po trzecie, prowadzono wobec nich tolerancyjną politykę wyznaniową, respektującą wolność religijną i charakterystyczne dla nich formy pobożności. Po czwarte, przesiedloną ludność osadzano w nowych miejscach w małych grupach albo rodzinami, co pomagało zachować więzi przyjacielskie i rodzinne. Taka polityka sprzyjała przejściu deportowanych od sytuacji wygnania do diaspory oraz zachowaniu przez nich swej kultury i religii ${ }^{73}$. Gdy po podboju Jerozolimy przez Babilończyków do głosu na wygnaniu doszli deportowani z Judy, ${ }^{74}$ przejęli dawne tradycje zachowane przez pobratymców, potomków deportowanych $\mathrm{z}$ dawnego królestwa Izraela i opracowali je na nowo

72 B. O d e d, Fundamentals of the Assyrian and Babylonian Policy of Exile in Connotation with the Study of the Israelite and Judean Exiles in Mesopotamia, w: Z. Ta ls h i r, Sh. Yon a, D. S iv a n (red.), Homage to Shmuel, Studies in the World of the Bible, Jerusalem 2001, s. 298-318.

73 W. C h r o s t o w s k i, Asyryjska diaspora Izraelitów-wyzwania i perspektywy badawcze, Collectanea Theologica 70(2000) nr 1, s. 7-24; toż w: t e n ż e, Asyryjska diaspora Izraelitów i inne studia, Rozprawy i Studia Biblijne 10, Warszawa 2003, s. $15-34$.

${ }^{74}$ Te n ż e, Babilońskie deportacje mieszkańców Jerozolimy i Judy (597-582 $r$. przed Chr.), w: te n ż e (red.), „Miłość wytrwa do końca” (1Kor 13,7). Księga Pamiątkowa dla Księdza Profesora Stanisława Pisarka w 50. rocznicę święceń kapłańskich i 75. rocznicę urodzin, Ad Multos Annos 9, Warszawa 2004, s. 96-138; to ż w: t e n ż e, Babilońskie deportacje mieszkańców Jerozolimy i Judy oraz inne studia, Rozprawy i Studia Biblijne 34, Warszawa 2009, s. 35-79. 
według własnego klucza, specyficznego dla ich spojrzenia. Wkrótce, aczkolwiek mogło się to dokonać już po powrocie z wygnania, orędzie Amosa, wygłoszone w pod koniec pierwszej połowy VIII w. przed Chr. i pieczołowicie zachowane na wygnaniu w Asyrii doczekało się finalnej redakcji w okresie wygnania babilońskiego, bądź/i w Judei po powrocie z wygnania, w której znalazły wyraz wybrane aspekty perspektywy jerozolimskiej.

ks. Waldemar CHROSTOWSKI 